\title{
Pembuatan Masker, Sarung Tangan Kain Sebagai Sarana Sosialisai Dan Edukasi Dampak Lingkungan Dalam Penanganan Covid-19 Oleh KKN ISI Denpasar Di Gianyar-Bali
}

\author{
I Gede Agus Indram Bayu Artha, Ni Kadek Riris Melati
}

Program Studi Desain Komunikasi Visual, Fakultas Seni Rupa dan Desain
Institut seni Indonesi Denpasar

1'goesindram@gmail.com, ${ }^{2} k d$ rirismelati@gmail.com

Pelaksanaan Kuliah Kerja Nyata (KKN) bertujuan untuk menumbuhkan rasa kepedulian mahasiswa terhadap berbagai masalah yang dihadapi masyarakat. Ditinjau dari permasalahannnya situasi pandemi juga memunculkan masalah baru bagi masyarakat dan lingkungan hidup, seperti rasa takut, cemas dan sampah dari masker dan sarung tangan sekali pakai meningkat dan mulai mengancam lingkungan. Sehubungan dengan masalah pencemaran lingkungan ini, program yang direncanakan untuk kegiatan KKN yang sesuai dengan bidang Desain adalah meningkatkan kesadaran akan pentingnya memilihara lingkungan dan meningkatkan kreatifitas dimasa pandemi dengan mengajak anak-anak dan pemuda/pemudi dalam membuat desain masker dan mengaplikasikannya dalam masker kain, sehingga dapat menggunakan produksi masker kain sendiri dan mengurangi penggunaan masker sekali pakai. Tujuan dari penulisan ini adalah untuk dijadikan rujukan KKN selanjutnya dan menambah pengetahuan secara akademis terhadap desain dan bagaimana desain bisa mengedukasi masyarakat tentang lingkungan. Adapun hal-hal yang akan dibahas adalah dampak covid 19 terhadap lingkungan masyarakat, cara mendasain masker kain, proses pembuatan dan perannnya dalam masyarakat. Pembahasan ini menggunakan rancangan penulisan secara kualitatif. Data dikumpulkan dengan metode observasi, wawancara dan dokumentasi. Hasil data yang didapat akan dianalisis dan dideskripsikan secara kualitatif sehingga dapat menarik kesimpulan sesuai dengan rumusan masalah.

Kata kunci: Kuliah Kerja Nyata, Masker Kain, Masyarakat.

Implementation of Real Work Lecture (KKN) aims to foster a sense of student concern for various problems faced by society. Judging from the problem, the pandemic situation also raises new problems for society and the environment, such as fear, anxiety and trash from disposable masks and gloves increasing and starting to threaten the environment. In connection with the problem of environmental pollution, the planned program for Community Service Program activities in accordance with the field of Design is to increase awareness of the importance of environmental choice and increase creativity during the pandemic by inviting children and youths / girls to design masks and apply them in cloth masks, so that can use their own cloth mask production and reduce the use of disposable masks. The purpose of this paper is to be used as a reference for further $\mathrm{KKN}$ and increase academic knowledge of design and how design can educate people about the environment. The things that will be discussed are the impact of covid 19 on the community environment, how to design cloth masks, the manufacturing process and its role in society. This discussion uses a qualitative writing design. Data were collected by means of observation, interviews and documentation. The results of the data obtained will be analyzed and described qualitatively so that conclusions can be drawn according to the formulation of the problem.

Keywords: Real Work Lecture, Cloth Masks, Society.

Proses review: 1 - 4 Mei 2021, Dinyatakan lolos 5 Mei 2021 


\section{PENDAHULUAN}

Kuliah Kerja Nyata (KKN) adalah merupakan kegiatan intrakulikuler yang memadukan pelaksanaan Tri Dharma Perguruan Tinggi dengan metode pemberian pengalaman belajar dan bekerja kepada mahasiswa dalam kegiatan pemberdayaan masyarakat. Kuliah Kerja Nyata ini mengharuskan mahasiswa berinteraksi dengan orang lain, terutama masyarakat didesa tempat mereka tinggal. Kemampuan seseorang untuk dapat berinteraksi dengan orang lain ini sering disebut denga keterampilan sosial. Keterampilan sosial adalah sebuah keterampilan yang dapat dipelajari, banyak aspek yang dapat mempengaruhi keterampilan sosial seseorang terutama aspek keluarga dan lingkungan. Namun pada tahun 2020 ini KKN Institut Seni Indonesia Denpasar ini berbeda dari tahun-tahun sebelumnya, hal ini dikarenakan adanya pandemi covid19 yang menyebabkan Kuliah Kerja Nyata ini dilaksanakan di Desa Daerah tempat tinggal masing-masing mahasiswa. Tetapi walaupun adanya pandemi covid19 tidak mematahkan semangat mahasiswa dalam melaksanakan Kuliah Kerja Nyata. Dengan dilaksanakan Kuliah Kerja Nyata ini di daerah masing-masing.

Pandemi virus covid19 telah membawa banyak perubahan dari berbagai aspek kehidupan. Salah satunya ialah sektor pendidikan, yang dimana pembelajaran dilakukan secara daring atau online. Demikian juga dengan Kuliah Kerja Nyata $(\mathrm{KKN})$ yang mengalami kendala dalam proses penyelenggaraannya. Tetapi walaupun adanya pandemi covid19 tidak mematahkan semangat mahasiswa dalam melaksanakan Kuliah Kerja Nyata. Dengan dilaksanakan Kuliah Kerja Nyata ini di daerah masing-masing membuat mahasiswa lebih mudah dalam menjalankan program kerja yang sudah dibuat dan memudahkan mahasiswa dalam berkomunikasi dengan aparat desa setempat. Pelaksanaan KKN bertujuan untuk menumbuhkan rasa kepedulian mahasiswa terhadap berbagai masalah yang dihadapi masyarakat. Mengingat situasi pandemi virus covid-19, KKN ISI Denpasar mengambil tema "KKN ISI Denpasar pada Masa Pandemi Covid-19 Turut Menberikan Edukasi Melalui Seni dan Budaya" yang dilaksanakan pada daerah tempat tinggal mahasiswa dengan menggunakan protokol kesehatan dan menerapkan social distancing. Pandemi covid19 memang memberi ruang bagi Bumi untuk istirahat sejenak. Berkurangnya polusi udara dan gas rumah kaca membuat Bumi sesaat menjadi lebih bersih dan bisa bernafas. Namun kondisi ini tidak berlangsung lama, karena nyatanya situasi pandemi juga memunculkan masalah baru bagi lingkungan hidup, seperti sampah dari masker dan sarung tangan sekali pakai meningkat drastis dan mulai mengancam lingkungan. Sehubung dengan masalah pencemaran lingkungan ini, program yang direncanakan untuk kegiatan Kuliah Kerja Nyata yang sesuai dengan bidang Desain Mode ialah meningkatkan kesadaran akan pentingnya memilihara lingkungan dan meningkatkan kreatifitas dimasa pandemi dengan mengajak anakanak dan pemuda/pemudi dalam membuat masker kain, sehingga dapat menggunakan produksi masker kain sendiri dan mengurangi penggunaan masker sekali pakai. Melakukan produksi masker dan sarung tangan kain untuk dibagikan kepada masyarakat di Desa Saba agar tetap mematuhi protokol kesehatan dan membuat pamplet yang berisikan tentang bagaimana pengaruh sampah masker dan sarung tangan sekali pakai terhadap lingkungan. Kondisi yang diharapkan setelah pelaksanaan kegiatan KKN ISI Denpasar dimasa covid-19 ialah agar masyarakat tetap mejaga kesehatan dan kebersihan diri tanpa melupakan pentingnya menjaga lingkungan. Dengan memperhatikan latar belakang yang telah diuraikan diatas maka adapun rumusan masalah yang ingin disampaikan antara lain,sebagai berikut: 1). Adakah dampak buruk dari covid 19 terhadap lingkungan. 2). bagaimana cara menanggulangi agar keaada lingkungan tidak semakin buruk? 3). Bagimana cara mengisi waktu luwang pemuda/pemudi dan anakanak di masa covid19 dengan hal positif ?

Teori Persepsi akan digunakan untuk menjawab rumusan masalah yang pertama, perancangan masker kain untuk menjawab permasalahan menanggulangi masker sekali pakai dan cara mengisi waktu luang untuk anak-anak dan pemuda di Desa Saba Gianyar Bali.

\section{Teori Persepsi}

Persepsi adalah pengalaman tentang objek, peristiwa, atau hubungan-hubungan yang diperoleh dengan menyimpulkan informasi dan menafsirkan pesan Persepsi adalah memberikan makna pada stimulus inderawi (sensory stimulus).

Persepsi ditentukan oleh :Faktor personal dan Faktor situasional.Sedangkan menurut David Krech dan Richard S. Crutchfield (1977:235), persepsi dipengaruhi : 


\section{Faktor Fungsional}

Faktor fungsional berasal dari kebutuhan, pengalaman masa lalu, dan hal-hal lain yang termasuk apa yang kita sebut sebagai faktor-faktor personal

\section{Faktor Struktural}

Faktor-faktor struktural berasal semata-mata dari sifat stimulus fisik dan efek-efek saraf yang ditimbulkannya pada sistem saraf individu.

Teori yang menggunakan faktor struktural ini adalah teori "GESTALT" yang dirumuskan oleh tiga psikolog Jerman : Kohler, Wartheimer, dan Koffka Pada faktor struktural, semua sifat individu yang berkaitan sifat kelompok akan dipengaruhi oleh keanggotaan kelompoknya, dengan efek yang berupa asimilasi atau kontras. Dalil-dalil persepsi menurut Krech dan Crutchfield adalah :

1. Persepsi bersifat selektif secara fungsional

2. Medan perseptual dan kognitif selalu diorganisasikan dan diberi arti

3. Sifat-sifat perseptual dan kognitif dari substruktur ditentukan pada umumnya oleh sifat-sifat struktur secara keseluruhan

4. Objek atau peristiwa yang berdekatan dalam ruang dan waktu atau menyerupai satu sama lain, cenderung ditanggapi sebagai bagian dari struktur yang sama.

Persepsi akan selalu berbeda pada setiap manusia, sehingga perlu untuk mengenal karakter dari manusia yang lain.

Teori perancangan desain masker dan sarung tangan. Program kegiatan dimulai dengan mengajak anakanak dan pemuda/pemudi untuk membuat masker kain dengan tujuan dengan tetap menerapkan protokol kesehatan dan melakukan social distancing. Dilanjutkan dengan memproduksi masker kain dan sarung tangan kain yang akan dibagikan kepada masyarakat. Melakukan pembagian masker kain dan sarung tangan kain pada pedagang agar mengurangi penggunaan masker dan sarung tangan sekali pakai. Dan memasang pamplet pada banjar dan kantor desa yang berisikan tentang pengaruh sampah masker dan sarung tangan sekali pakai terhadap lingkungan.

\section{METODE PENELITIAN}

Menggunakan jenis penelitian kualitatif untuk mengumpulkan, memilih dan menganalisis data. Menurut Bogdan dan Taylor (dalam Kaelan,
2005:5) penelitian kualitatif adalah penelitian yang menghasilkan data deskriptif berupa kata-kata, catatan-catatan yang berhubungan dengan makna, nilai dan pengertian. Dengan demikian, segala hal yang berhubungan dengan Pembuatan masker kain di Desa Saba Kabupaten Gianyar Bali akan dideskripsikan secara kualitatif.

Tahapan yang akan dilakukan dalam menyelesaikan Pembuatan masker sebagai sosialisasi dan edukasi dampak lingkungan pada masa pandemic covid 19 ini adalah yang pertama, menentukan masalah yang ada dimasyarakat Desa Saba Gianyar, dalam tahapan ini penulis mengadakan studi pendahuluan tentang desa tersebut, lingkungan dan masyarakatnya, dan proses pembuatan masker kain yang dilakukan oleh anakanak dan pemuda/i.. kedua, tahap pengumpulan data, pada tahapan ini penulis akan menentukan sumber data dengan pengumpulan data yang menggunakan metode observasi, kepustakaan dan wawancara. Tahap ketiga adalah analisis dan penyajian data, dalam tahapan ini peneliti menganalisis data yang sudah terkumpul dan terakhir menarik kesimpulan dari hasil penulisan ini.

Penelitian ini difokuskan pada dampak masker sekali pakai, sosialisasi dan edukasi, serta cara membuat masker dan sarung tangan kain. penelitian tersebut didasarkan pada analisis persepsi masyarakat, serta analisi proses pembuatan masker kain dan sarung tangan kain sebagai solusi terhadap pencemaran lingkungan. Analisa data yang digunakan dalam penelitian ini adalah teknik deskriftif kualitatif yaitu memberikan uraian secara deskripsi tentang dampak yang ditimbulkan dari covid 19, cara mengisi waktu kosong dan cara membuat masker dan sarung tangan kain. Deskriptif Kualitatif menekankan pada penjabaran data yang didapat dilapangan dikaitkan dengan teori teori persepsi dan proses perancangan desain masker dan sarung tangan. sehingga didapatkan hasil yang jelas dari permasalahanpermasalahan yang muncul dari pelaksanaan $\mathrm{KKN}$ ini. Setelah semua data terkumpul dianalisis dan dibahas secara mendalam, selanjutnya adalah menarik kesimpulan dari apa yang sudah diuraikan dalam Persepsi masyarakat dan proses pembuatan masker kain serta sarung tangan kain sebagai sarana sosialisasi dan edukasi dampak lingkungan masa pandemic covid 19 di Desa Saba Kabupaten GianyarBali. 


\section{HASIL DAN PEMBAHASAN}

Pembahasan ini akan menjawab rumusan masalah yang berkaitan dengan persepsi masyarakat tentang dampak buruk covid 19 terhadap lingkungan. berikut adalah pembahasan persepsi dari masyarakat desa saba tersebut.

Persepsi Merupakan Proses mengidentifikasi dari penerimaan yang diterima oleh indera manusia. Persepsi dalam psikologi juga memiliki konsep tersendiri. Bila dikaitkan dengan teori psikologi komunikasi, maka persepsi ini merupakan bagian dari proses komunikasi intrapersonal. Adapun persepsi yang muncul dari masyarakat terkait dengan dampak dari covid 19 terhadap lingkungan.

\section{Ketakutan}

Perasaan takut dapat menjadi salah satu contoh dari bentuk persepsi, pada kasus covid 19 ini menimbulkan rasa takut terhadap masyarakat, takut akan terpapar virus, takut dikarantina, dan takut akan kesehatan keluarga dan yang terakhir takut dampaklingkungan yang memburuk karena sampah masker dan sarung tangan sekali pakai.

\section{Kepanikan}

Sama halnya dengan pembahasan di atas, kepanikan bisa timbul karena adanya sensasi melihat situasi tertentu, seperti situasi pada masa pandemi covid 19 ini. Rasa panic ini merupakan hasil persepsi dari sensasi atau stimulus yang diterima oleh masyarakat, khususnya masyarakat Desa saba Gianyar. Dikaitkan dengan masalah yang muncul sudah pasti masyarakat akan merasa panik dengan media yang menjejali masyarakat dengan bahayanya virus covid dan dampaknya terhadap lingkungan dan sosial masyarakat.

\section{Kekhawatiran}

Rasa Khawatir adalah bentuk rasa cemas pada objek yang tidak jelas, tidak nyata atau sulit untuk digambarkan secara konkret. Sensasi yang diterima seseorang juga biasanya muncul setelah seseorang melihat sesuatu yang membuatnya terancam pula. Situasi ini membuat pesepsi seseorang menjadi muncul dalam bentuk kekhawatiran. Kekhawatiran masyarakat sudah jelas pasti ada, virus yang bisa mematikan dan dampak lingungan yang ditimbulkan membuat perasaan mayarakat Desa Sabe tidaklah tenang sampai pandemi ini berakhir.

\section{Perasaan Negatif}

Perasaan/pemikiran negative adalah sebuah hasil dari persepsi manusia. Persaaan ini merupakan hal yang manusiawi yang dimiliki oleh manusia. Dengan adanya stimulus dari masalah pandemic covid 19 ini sudah pasti akan memunculkan perasaan atau pemikiran yang negative, antara ketakutan, kepanikan dan kekhawatiran tersebut.

Dari penjabaran persepsi diatas maka dapat dideskripsikan masyarakat desa saba kabupaten gianyar mempunya persepsi dampak buruk yang di hasilkan atau dimunculkan dari pandemic covid 19 ini. Baik dari segi kesehatan, pemikiran, lingkungan dan social budaya.

Selanjutnya untuk menjawab permasalahan kedua yaitu bagimana menanggulangi agar lingkungan dan kondisi masyarakat tidak semakin buruk berikut adalah penjabarannya dari kegiatan KKN tersebut. Program kegiatan dimulai dengan mengajak anakanak dan pemuda/pemudi untuk membuat masker kain dengan tujuan dengan tetap menerapkan protokol kesehatan dan melakukan social distancing. Dilanjutkan dengan memproduksi masker kain dan sarung tangan kain yang akan dibagikan kepada masyarakat. Melakukan pembagian masker kain dan sarung tangan kain pada pedagang agar mengurangi penggunaan masker dan sarung tangan sekali pakai. Dan memasang pamplet pada banjar dan kantor desa yang berisikan tentang pengaruh sampah masker dan sarung tangan sekali pakai terhadap lingkungan. 


\begin{tabular}{|c|c|c|c|c|c|c|}
\hline No & $\begin{array}{l}\text { Nama } \\
\text { Kegiatan }\end{array}$ & Sasaran & $\begin{array}{l}\text { Penanggung } \\
\text { Jawab }\end{array}$ & $\begin{array}{l}\text { Teknik } \\
\text { Pelaksanaan }\end{array}$ & $\begin{array}{l}\text { Waktu } \\
\text { Pelaksanaan }\end{array}$ & $\begin{array}{l}\text { Perkiraan } \\
\text { Biaya }\end{array}$ \\
\hline 1 & $\begin{array}{l}\text { Praktek pembuatan } \\
\text { masker kain }\end{array}$ & $\begin{array}{l}\text { Anak-anak dan } \\
\text { Pemuda/ pemudi }\end{array}$ & $\begin{array}{l}\text { I Gede Agus } \\
\text { Indram Bayu } \\
\text { Artha } \\
\text { Ni Kadek } \\
\text { Riris Melati }\end{array}$ & $\begin{array}{l}\text {-Mempraktikan } \\
\text { cara pembuatan } \\
\text { masker kain } \\
\text {-Memberi } \\
\text { informasi } \\
\text { pengaruh buruk } \\
\text { masker sekali } \\
\text { pakai terhadap } \\
\text { lingkungan }\end{array}$ & $\begin{array}{l}\text { Minggu } \\
\text { pertama }\end{array}$ & - \\
\hline 2 & $\begin{array}{l}\text { Proses produksi } \\
\text { masker dan sarung } \\
\text { tangan kain }\end{array}$ & Masyarakat & $\begin{array}{l}\text { I Gede Agus } \\
\text { Indram Bayu } \\
\text { Artha } \\
\text { Ni Kadek } \\
\text { Riris Melati }\end{array}$ & $\begin{array}{l}\text {-Membuat desain } \\
\text { masker dan } \\
\text { sarung tangan } \\
\text {-Menyiapkan alat } \\
\text { dan bahan yang } \\
\text { diperlukan } \\
\text {-Melakukan } \\
\text { proses } \\
\text { pembuatan pola } \\
\text { dan menjahit }\end{array}$ & $\begin{array}{l}\text { Minggu kedua } \\
\text { s/d minggu } \\
\text { ketiga }\end{array}$ & $\begin{array}{l}\text { Rp. } \\
500.000\end{array}$ \\
\hline 3 & $\begin{array}{l}\text { Pembagian masker } \\
\text { dan sarung tangan } \\
\text { kain }\end{array}$ & Masyarakat & $\begin{array}{l}\text { I Gede Agus } \\
\text { Indram Bayu } \\
\text { Artha } \\
\text { Ni Kadek } \\
\text { Riris Melati }\end{array}$ & $\begin{array}{l}\text {-Melakukan } \\
\text { pembagian } \\
\text { masker dan } \\
\text { sarung tangan } \\
\text { kain kepada } \\
\text { para pedagang }\end{array}$ & $\begin{array}{l}\text { Minggu ke } \\
\text { empat }\end{array}$ & - \\
\hline 4 & $\begin{array}{l}\text { Pemasangan } \\
\text { pamplet di banjar } \\
\text { dan kantor desa }\end{array}$ & Masyarakat & $\begin{array}{l}\text { I Gede Agus } \\
\text { Indram Bayu } \\
\text { Artha } \\
\text { Ni Kadek } \\
\text { Riris Melati }\end{array}$ & $\begin{array}{l}\text {-Memasang } \\
\text { pamflet di banjar } \\
\text { dan kantor } \\
\text { desa dengan } \\
\text { tujuan memberi } \\
\text { edukasi tentang } \\
\text { pentingnya } \\
\text { pemeliharaan } \\
\text { lingkungan pada } \\
\text { masa pandemi } \\
\text { COVID-19 }\end{array}$ & & $\begin{array}{l}\text { Rp. } \\
100.000\end{array}$ \\
\hline
\end{tabular}


Selanjutnya untuk menjawab permasalahan ketiga yaitu Bagimana cara mengisi waktu luwang pemuda/ pemudi dan anak-anak di masa covid19 dengan hal positif. Adapun cara yang dilakukkan adalah dengan membuat kegiatan mengaplikasikan desain masker dan sarung tangan kedalam wujud aslinya. Hasil pelaksanaan Kegiatan di Desa Saba Kecamatan Blahbatuh Kabupaten Gianyar ialah ditampilakn dalam bentuk Tabel di bawah ini.

Tabel Kegiatan

\begin{tabular}{|c|c|c|}
\hline TANGGAL & $\begin{array}{l}\text { PROGRAM } \\
\text { KEGIATAN }\end{array}$ & PELAKSANAAN \\
\hline $01 / 08 / 2020$ & $\begin{array}{l}\text { Melakukan } \\
\text { Pendataan } \\
\text { Peserta }\end{array}$ & $\begin{array}{l}\text { Mahasiswa melakukan } \\
\text { kegiatan pendataan } \\
\text { peserta yang akan } \\
\text { mengikuti praktek } \\
\text { pembuatan masker } \\
\text { kain, yang akan } \\
\text { dilaksanakan di Balai } \\
\text { Banjar Banda }\end{array}$ \\
\hline $03 / 08 / 2020$ & $\begin{array}{l}\text { Menyiapkan alat } \\
\text { dan bahan }\end{array}$ & $\begin{array}{l}\text { Mahasiswa } \\
\text { menyiapkan } \\
\text { bahan dengan } \\
\text { mengumpulkan perca } \\
\text { yang bisa digunakan } \\
\text { sebagai masker, } \\
\text { mempersiapkan karet } \\
\text { dan menyiapkan alat } \\
\text { yang akan digunakan } \\
\text { seperti gunting, jarum } \\
\text { jahit,jarum pentul, } \\
\text { kapur, benang dan } \\
\text { meteran. }\end{array}$ \\
\hline $04 / 08 / 2020$ & $\begin{array}{l}\text { Membuat pola } \\
\text { masker dan } \\
\text { menyiapkan } \\
\text { layout }\end{array}$ & $\begin{array}{l}\text { Mahasiswa melakukan } \\
\text { proses pembuatan } \\
\text { pola masker yang } \\
\text { akan digunakan } \\
\text { untuk praktek } \\
\text { pembuatan masker } \\
\text { dan menyiapkan layout } \\
\text { sebagai panduan dalam } \\
\text { pembuatan masker. }\end{array}$ \\
\hline
\end{tabular}

\begin{tabular}{|c|c|c|}
\hline $05 / 08 / 2020$ & $\begin{array}{l}\text { Melakukan } \\
\text { praktek } \\
\text { pembuatan } \\
\text { masker dan } \\
\text { memberi } \\
\text { informasi } \\
\text { kepada peserta } \\
\text { tentang dampak } \\
\text { masker sekali } \\
\text { pakai terhadap } \\
\text { lingkungan. }\end{array}$ & $\begin{array}{l}\text { Mahasiswa mengajak } \\
\text { pemuda/pemudi dan } \\
\text { anak-anak untuk } \\
\text { membuat masker kain } \\
\text { dengan menggunakan } \\
\text { teknik jahit tikam } \\
\text { jejak, serta mahasiswa } \\
\text { memberikan edukasi } \\
\text { terhadap dampak } \\
\text { buruk yang terjadi } \\
\text { terhadap lingkungan } \\
\text { jika menggunakan } \\
\text { masker sekali pakai } \\
\text { dan kegiatan ini } \\
\text { dilaksanakan di Balai } \\
\text { Banjar Banda Desa } \\
\text { Saba. }\end{array}$ \\
\hline $10 / 08 / 2020$ & $\begin{array}{l}\text { Memilih ukuran, } \\
\text { mempersiapkan } \\
\text { desain masker } \\
\text { dan membuat } \\
\text { pola. }\end{array}$ & $\begin{array}{l}\text { Mahasiswa } \\
\text { mempersiapkan } \\
\text { ukuran standar serta } \\
\text { membuat pola masker } \\
\text { untuk diproduksi } \\
\text { sendiri dan mahasiswa } \\
\text { mempersiapkan desain } \\
\text { yang fashionable } \\
\text { dan nyaman untuk } \\
\text { digunakan. }\end{array}$ \\
\hline $11 / 08 / 2020$ & $\begin{array}{l}\text { Meyiapkan alat } \\
\text { dan bahan untuk } \\
\text { produksi }\end{array}$ & $\begin{array}{l}\text { Mahasiswa melakukan } \\
\text { proses pembelian } \\
\text { dan pemilihan bahan } \\
\text { utama dan pelapis } \\
\text { yang nyaman untuk } \\
\text { nantinya digunakan, } \\
\text { adapun bahan utama } \\
\text { yang digunakan ialah } \\
\text { kain katun sedangkan } \\
\text { bahan pelapisnya } \\
\text { ialah kain hero tebal. } \\
\text { Mahasiswa juga } \\
\text { mempersiapkan } \\
\text { bahan pendukung } \\
\text { seperti karet yang } \\
\text { akan digunakan, } \\
\text { serta mahasiswa } \\
\text { mempersiapkan } \\
\text { alat berupa gunting, } \\
\text { benang, kapur, meteran } \\
\text { serta jarum pentul. }\end{array}$ \\
\hline
\end{tabular}




\begin{tabular}{lll}
\hline 12/08/2020 & Melakukan & Pemotongan bahan \\
& proses & dilakukan oleh \\
& pemotongan & mahasiswa dengan \\
& bahan masker & jumblah 120 buah \\
& & bahan utama dan \\
bahan pelapis, & serta melakukan \\
& & pemotongan karet yang \\
& & akan dipasang pada \\
& & bagian sisi kanan kiri \\
& & masker. \\
\hline 13/08/2020 & Melakukan & Proses menjahit \\
& proses menjahit & masker dilakukan \\
16/08/2020 & masker & oleh mahasiswa, yang \\
& & dilakukan ditempat \\
& & tinggal mahasiswa \\
\hline 17/08/2018 & Mempersiapkan & Mahasiswa membuat \\
& pola sarung & pola sarung tangan \\
& tangan dengan & dengan menggunakan \\
& menggunakan & ukuran standar, \\
& ukuran standar & ukuran standar \\
& & yang digunakan \\
& mahasiswa didapat \\
& & dari pembuatan sample \\
& & dan diuji coba kepada \\
& & beberapa orang. \\
& &
\end{tabular}

\begin{tabular}{|c|c|c|}
\hline $18 / 08 / 2020$ & $\begin{array}{l}\text { Mempersiapkan } \\
\text { alat dan bahan } \\
\text { yang akan } \\
\text { digunakan dan } \\
\text { melakukan proses } \\
\text { pemotongan } \\
\text { bahan }\end{array}$ & $\begin{array}{l}\text { Mahasiswa memilih } \\
\text { bahan cotton combed, } \\
\text { karena sesuai untuk } \\
\text { digunakan sebagai } \\
\text { bahan sarung tangan, } \\
\text { mahasiswa juga } \\
\text { mempersiapkan } \\
\text { alat berupa benang, } \\
\text { gunting, kapur } \\
\text { dan meteran. Serta } \\
\text { mahasiswa melakukan } \\
\text { proses pemotongan } \\
\text { bahan sarung tangan. }\end{array}$ \\
\hline $\begin{array}{l}19 / 08 / 2020 \\
\text { s/d } \\
22 / 08 / 2020\end{array}$ & $\begin{array}{l}\text { Melakukan } \\
\text { proses penjahitan }\end{array}$ & $\begin{array}{l}\text { Mahasiswa melakukan } \\
\text { proses menjahit sarung } \\
\text { tangan di tempat } \\
\text { tinggal mahasiswa }\end{array}$ \\
\hline $23 / 08 / 2020$ & $\begin{array}{l}\text { Mempersiapkan } \\
\text { pamflet edukasi } \\
\text { tentang masker } \\
\text { sekali pakai }\end{array}$ & $\begin{array}{l}\text { Mahasiswa } \\
\text { mempersiapkan desain } \\
\text { untuk pamflet edukasi } \\
\text { dan mahasiswa juga } \\
\text { melakukan proses } \\
\text { pencetakan pamflet } \\
\text { yang akan dipasang } \\
\text { dikantor desa dan } \\
\text { banjar }\end{array}$ \\
\hline
\end{tabular}

\begin{tabular}{|c|c|c|}
\hline $26 / 08 / 2020$ & $\begin{array}{l}\text { Melakukan } \\
\text { proses } \\
\text { pengemasan } \\
\text { masker dan } \\
\text { sarung tangan }\end{array}$ & $\begin{array}{l}\text { Mahasiswa melakukan } \\
\text { pengemasan dan } \\
\text { membagi masker yang } \\
\text { akan diserahkan ke } \\
\text { kantor Kepala Desa dan } \\
\text { yang akan dibagikan } \\
\text { kepada para pedagang } \\
\text { di Desa Saba. }\end{array}$ \\
\hline $27 / 08 / 2020$ & $\begin{array}{l}\text { Membagikan } \\
\text { masker dan } \\
\text { sarung tangan } \\
\text { kain serta } \\
\text { melakukan } \\
\text { pemasangan } \\
\text { pamflet }\end{array}$ & $\begin{array}{l}\text { Proses pembagian } \\
\text { masker dan sarung } \\
\text { tangan dilakukan } \\
\text { oleh mahasiswa } \\
\text { untuk para pedagang } \\
\text { dan dikantor Kepala } \\
\text { Desa, yang bertujuan } \\
\text { untuk mengurangi } \\
\text { penyebaran virus } \\
\text { corona serta melakukan } \\
\text { pemasangan pamflet } \\
\text { yang bertujuan } \\
\text { untuk mengingatkan } \\
\text { masyarakat menjaga } \\
\text { lingkungan dengan } \\
\text { mengurangi } \\
\text { penggunaan masker } \\
\text { dan sarung tangan } \\
\text { sekali pakai. }\end{array}$ \\
\hline
\end{tabular}

\section{Faktor Penghambat dan Pendukung Pelaksanaan Kegiatan KKN Pada Masa Covid-19}

Faktor penghambat yang dihadapi saat melaksanakan kegiatan Kuliah Kerja Nyata pada masa covid19 ialah kurangnya sumber daya manusia yang dikarena pelaksanaan Kuliah Kerja Nyata tahun ini di desa atau daerah tempat tinggal masing-masing, sehingga pelaksanaan proses produksi masker tidak dapat dibuat dalam jumblah yang begitu besar. Sedangkan faktor pendukung terhadap pelaksanaan program Kuliah Kerja Nyata yang dilaksanakan di Desa Saba yaitu simpati atau respon positif yang didapat dari masyarakat serta bantuan dari pihak desa yang mempermudah dalam melaksanakan program kegiatan yang sudah dibuat.

\section{SIMPULAN}

Pelaksanaan Kuliah Kerja Nyata dalam masa pandemic memberikan banyak manfaat dan dampak bagi masyarakat. Dimana pandemi covi19 ini memberikan banyak dampak bagi kehidupan. Salah satunya ialah dampak buruk terhadap masyarakat dan lingkungan. Masalah baru yang terjadi pada masyarakat adalah rasa takut, khawatir dan pikiran 
yang selalu muncul dalam benak masyarakat. hal ini harus segera ditangani dengan mengisi waktu kosong dirmh dengan hal-hal yang positif. Selanjutnya dampak terhadap lingkungan hidup ini berupa sampah masker dan sarung tangan sekali pakai yang mengakibatkan pencemaran lingkungan. Upaya yang dapat dilakukan dalam program Kuliah Kerja Nyata ISI Denpasar ini ialah mendesain dan mengaplikasikannya kedalam bentuk masker kain. Setelah aske dibuat dan mengedukasi masyarakat tentang lingkungan selanjutnya membagikan masker dan sarung tangan berbahan kain serta mengajak masyarakat untuk terkonsentrasi di bidang kesehatan dengan menggunakan masker dan sarung tangan berbahan kain guna mengurangi pencemaran terhadap lingkungan. Kegiatan kerja lainnya yang dapat dilakukan pada masa pandemi ini ialah mengajak pemuda/ pemudi dan anakanak untuk melakukan praktek pembuatan masker kain serta memberikan informasi mengenai dampak buruk masker dan sarung tangan sekali pakai. Selain mengedukasi kegiatan ini bertujuan untuk meningkatkan kreatifitas pemda/pemudi di Desa Saba sehingga dapat memanfaatkan waktu luwangnya dengan hal yang positif. Adapun harapan setelah program ini terlaksana, masyarakat di Desa Saba dapat mengerti akan pentingnya menjaga kesehatan dan kebersihan lingkungan.

\section{DAFTAR RUJUKAN}

Jay,Ros. 2007. Menulis Proposal dan Laporan. Jakarta : PT Bhuana Ilmu Populer.

Moleong, Lexy. 2001. Metodelogi Penelitian Kualitatif. Bandung: Remaja Rosdakarya.

Syardiansyah.2019.Peranan Kuliah Kerja Nyata Sebagai Bagian Dari Pengembangan Kompetensi Mahasiswa,Ejournal, 7(1), 57-58

Zaharah Zaharah, Galia Ildusovna Kirilova, Anissa Windarti.2020. Impact Of Corona Virus Outbreak Towards Teaching And Learning Activities In Indonesia. Journal.Uinjkt,

Rachmatunisa. 2020. Sampah masker dan sarung tangan jadi ancaman lingkungan era new normal. https://inet.detik.com/science/d-5048117/ sampah-masker-dan-sarung-tangan-jadi-ancamanlingkungan-era-new-normal.
(Anonim).2017. profil desa saba. Kantor Desa Saba 